\title{
PELATIHAN PEMBUATAN PUBLIKASI ILMIAH GURU-GURU SMA N 2 TAMBANG KABUPATEN KAMPAR
}

\author{
Jufrizal Syahri*, Rahmiwati Hilma, Hasmalina Nasution, Prasetya, \\ Rahmadini Syafri, Sri Hilma Siregar, Nurlaili \\ Program Studi Kimia, Fakultas MIPA \& Kesehatan \\ Universitas Muhammadiyah Riau \\ email : jsyachri@gmail.com
}

\begin{abstract}
The writing of scientific writing is one of the efforts to develop the profession of teachers of SMA N 2 Tambang in Kampar regency. This training aims to equip teachers in terms of strategies to develop scientific papers properly in accordance with the guidelines of writing, and equip teachers in the publication procedures of scientific papers in the journal. The training of scientific writing is done by varied lecture method and practice. The lecture method is needed to explain the procedure for the preparation of scientific papers, including how to arrange classroom action research into a scientific paper. Methods of practice are needed to allow the participants to write scientific papers in the form of articles for journals. The training activities of the writing of scientific papers as a whole can be said to be well seen from the achievement of the target of the trainee, the achievement of the training objectives, the achievement of the planned material targets, and the ability of the participants in the mastery of the material. The supporting factors for the implementation of Community Service activities are the availability of experts in SMA N 2 Tambang, the enthusiasm of the participants, the support of the principal of the place of administration, and the supporting funds of the faculty.
\end{abstract}

Key words : Scientific Writing, Professional Teacher Development

\begin{abstract}
Abstrak
Pelatihan penulisan karya tulis ilmiah merupakan salah satu upaya untuk pengembangan profesi guru-guru SMA N 2 Tambang di Kabupaten Kampar. Pelatihan ini bertujuan untuk membekali guru dalam hal strategi menyusun karya tulis ilmiah secara benar sesuai dengan pedoman penulisan, dan membekali guru dalam prosedur publikasi karya tulis ilmiah dalam jurnal. Pelatihan penulisan karya tulis ilmiah dilakukan dengan metode ceramah bervariasi dan latihan/praktik. Metode ceramah diperlukan untuk menjelaskan prosedur penyusunan karya tulis ilmiah, termasuk di dalamnya bagaimana menyusun penelitian tindakan kelas menjadi sebuah karya tulis ilmiah. Metode latihan/praktik diperlukan untuk memberi kesempatan kepada peserta menulis karya tulis ilmiah berupa artikel untuk jurnal. Kegiatan pelatihan penulisan karya tulis ilmiah ini secara keseluruhan dapat dikatakan baik dilihat dari ketercapaian target peserta pelatihan, ketercapaian tujuan pelatihan, ketercapaian target materi yang direncanakan, dan kemampuan peserta dalam penguasaan materi. Faktor pendukung terlaksananya kegiatan Pengabdian Masyarakat ini adalah ketersediaan tenaga ahli di SMA N 2 Tambang, antusiasme peserta, dukungan kepala sekolah tempat penyelenggaraan, dan dana pendukung dari fakultas.
\end{abstract}

Kata kunci: Karya Tulis Ilmiah, Pengembangan Profesi Guru 


\section{PENDAHULUAN}

Karya ilmiah merupakan salah satu kewajiban yang harus dipenuhi oleh para guru sebagai persyaratan peningkatan jenjang karir (pangkat/golongan) berdasarkan Permenpan RB nomor Per/16/MENPAN-RB/11/2009 tanggal 10 Nopember 2009, tentang : Jabatan Fungsional Guru dan Angka Kreditnya. Saat ini, penulisan karya ilmiah dalam bentuk jurnal ilmiah masih menjadi beban bagi para guru. Hal ini disebabkan keterbatasan pengetahuan yang mereka miliki tentang teknis penulisan jurnal ilmiah yang baik. Beberapa karya ilmiah yang mereka hasilkan seringkali belum sesuai dengan kaidah penyusunan jurnal ilmiah, bahkan banyak dijumpai karya yang sarat dengan plagiasi. Berdasarkan hal tersebut, maka perlu dilakukan pelatihan untuk para guru khususnya guru tingkat SMA tentang tata cara penulisan jurnal ilmiah yang baik dan memenuhi standar keilmuan.

Guru memiliki tiga tugas pokok dan fungsi (TUPOKSI) yaitu: pendidikan, proses pembelajaran, dan pengembangan profesi sebagai penunjang proses pembelajaran. Jurnal ilmiah termasuk ke dalam pengembangan profesi keguruan. Oleh karena itu, seorang guru professional dituntut untuk bisa menghasilkan karya/publikasi dalam bentuk jurnal ilmiah. Sementara itu, dosen memiliki tugas yang disebut Tri Darma Perguruan Tinggi, yaitu: Pengajaran, penelitian, dan pengabdian kepada masyarakat. Memberikan informasi dan pelatihan kepada guru-guru tentang publikasi ilmiah merupakan bagian dari pengabdian kepada masyarakat.

Pelatihan penulisan publikasi ilmiah untuk guru ini menjadi sangat urgent saat ini. Hal ini disebabkan tidak akan terciptanya guru yang professional apabila guru-guru tidak mampu menulis publikasi ilmiah. Sementara itu, disisi lain kemajuan suatu bangsa juga sangat ditentukan oleh kualitas dari pendidiknya. Maka melalui pelatihan ini, diharapkan dapat membantu mewujudkan guru-guru professional yang mampu menulis publikasi dalam jurnal ilmiah.

Kurangnya wawasan dan pengetahuan guru-guru tentang publikasi ilmiah menjadi permasalahan utama yang terjadi saat ini. Akibat dari permasalahan ini, menciptakan guruguru yang tidak profesional di bidangnya. Hal ini juga menjadi penghambat bagi guru untuk naik pangkat/golongan dari Iva ke IVb. Oleh karena itu, untuk meningkatkan wawasan guru-guru khususnya tingkat SMA di Kabupaten Rokan Hulu, dapat dilakukan mengadakan Pelatihan Pembuatan Publikasi Ilmiah. Pelatihan ini diharapkan dapat mengembangkan wawasan para guru khususnya tingkat SMA tentang bagaimana caranya membuat publikasi yang baik dan terhindar dari tindakan plagiasme, sehingga dapat menjadi guru yang profesional. Harapan kedepannya para guru yang mengikuti pelatihan dapat menghasilkan publikasi ilmiah dan menjadi contoh untuk guru-guru yang lainnya.

\section{Solusi dan Target Luaran Jenis- Jenis Publikasi Ilmiah (Dwianto, 2016)}

Publikasi ilmiah merupakan wadah bagi para dosen/guru untuk menyampaikan gagasan ilmiah hasil penelitian dan kajian akademik lainnya, yang berupa artikel maupun hasil telahaan dan disampaikan pada media/forum ilmiah. Jenis-jenis publikasi ilmiah adalah

1. Presentasi pada forum ilmiah

a) Menjadi nara sumber pada seminar atau lokakarya ilmiah. 
b) Menjadi nara sumber pada koloqium atau diskusi ilmiah

2. Laporan hasil penelitian

a) Laporan hasil penelitian yang diterbitkan/dipublikasikan dalam bentuk buku ber ISBN dan telah mendapat pengakuan BSNP.

b) Laporan hasil penelitian yang disusun menjadi artikel ilmiah diterbitkan/dipublikasikan dalam majalah ilmiah/jurnal ilmiah diedarkan secara nasional dan terakreditasi.

c) Laporan hasil penelitian yang disusun menjadi artikel ilmiah diterbitkan/dipublikasikan dalam majalah/jurnal ilmiah tingkat provinsi.

d) Laporan hasil penelitian yang disusun menjadi artikel ilmiah diterbitkan/dipublikasikan dalam majalah/jurnal ilmiah tingkat kabupaten/kota.

e) Laporan hasil penelitian yang diseminarkan di sekolah/madrasahnya dan disimpan di perpustakaan.

3. Makalah berupa tinjauan ilmiah di bidang pendidikan formal dan pembelajaran

Makalah tinjauan ilmiah adalah karya tulis guru yang berisi ide/gagasan penulis dalam upaya mengatasi berbagai masalah pendidikan formal dan pembelajaran yang ada di satuan pendidikannya sekolah/madrasahnya).

4. Tulisan ilmiah popular

Karya ilmiah populer adalah tulisan ilmiah yang dipublikasikan di media massa (koran, majalah, atau sejenisnya).

5. Artikel ilmiah dalam bidang pendidikan

Artikel ilmiah dalam bidang pendidikan adalah tulisan yang berisi gagasan atau tinjauan ilmiah dalam bidang pendidikan formal dan pembajaran di satuan pendidikan yang dimuat di jurnal ilmiah.
6. Publikasi buku teks pelajaran, buku pengayaan, dan/atau pedoman guru

Buku pelajaran adalah buku berisi pengetahuan untuk bidang ilmu atau mata pelajaran tertentu dan diperuntukkan bagi siswa pada suatu jenjang pendidikan tertentu atau sebagai bahan pegangan mengajar guru, baik sebagai buku utama atau buku pelengkap.

7. Modul/diktat pembelajaran per semester

a) Modul adalah materi pelajaran yang disusun dan disajikan secara tertulis sedemikian rupa sehingga pembacanya diharapkan dapat menyerap sendiri materi tersebut.

b) Diktat adalah catatan tertulis suatu mata pelajaran atau bidang studi yang dipersiapkan guru untuk mempermudah/memperkaya materi mata pelajaran/bidang studi yang disampaikan oleh guru dalam proses kegiatan belajar mengajar.

8. Buku dalam bidang pendidikan

Buku dalam Bidang Pendidikan merupakan buku yang berisi pengetahuan terkait dengan bidang kependidikan.

9. Karya terjemahan

Karya terjemahan adalah tulisan yang dihasilkan dari penerjemahan buku pelajaran atau buku dalam bidang pendidikan dari bahasa asing atau bahasa daerah ke Bahasa Indonesia atau sebaliknya dari Bahasa Indonesia ke bahasa asing atau bahasa daerah.

Buku terjemahan tersebut harus dilengkapi dengan surat pernyataan dari kepala sekolah/madrasah yang menjelaskan perlunya karya terjemahan tersebut untuk menunjang proses pembelajaran disertai tanda tangan kepala sekolah/madrasah dan cap sekolah/ madrasah bersangkutan.

10. Buku pedoman guru 
Buku pedoman guru adalah buku tulisan guru yang berisi rencana kerja tahunan guru.

\section{Solusi yang Diberikan}

Pelatihan ini akan memberikan informasi dan tata cara membuat sebuah publikasi berupa jurnal ilmiah, sehingga diharapkan dapat menjadi solusi dalam pembuatan artikel ilmiah para guru-guru saat ini. Setelah pelatihan ini, guru-guru diminta untuk lebih produktif dalam menghasilkan karya ilmiah, sebagai wujud terciptanya guru-guru profesional.

Peran aktif dari para guru juga sangat penting untuk terciptanya target yang diharapkan. Paradigma bahwa guru hanya mengajar di kelas juga harus dihilangkan, sehingga guru merasa memiliki kewajiban untuk melakukan penelitian. Hasil-hasil penelitian dari guru inilah yang akan dibuat dalam bentuk jurnal ilmiah.

\section{Target Luaran}

Luaran dari pelatihan ini berupa laporan pelaksanaan dan materi pelatihan, yang dapat digunakan sebagai acuan dalam pembuatan jurnal ilmiah oleh para guru-guru. Guru-guru yang mendapatkan pelatihan diharapkan juga dapat menyebarkan informasi dan membimbing guru-guru lain dalam membuat publikasi ilmiah. Melalui cara ini penyebaran informasi dapat berjalan lebih cepat.

\section{METODE PENGABDIAN}

Pelatihan pembuatan jurnal ilmiah ini akan dilakukan di SMAN 2 Tambang, dan pesertanya merupakan guru-guru SMA yang berada di sekitar SMAN 2 Tambang. Pelatihan ini direncanakan akan dilaksanakan pada pertengan bulan Februari 2018.

\section{Metode Pelatihan}

Pelatihan dilakukan dengan metoda ceramah, kemudian dilanjutkan dengan praktek pembuatan jurnal ilmiah oleh peserta pelatihan. Output yang diharapkan setelah acara adalah, masing-masing peserta memiliki sebuah artikel yang sudah siap untuk di publikasikan dalam jurnal ilmiah.

\section{Narasumber}

Narasumber yang memberikan pelatihan terdiri dari 6 orang, dengan bidang masing-masing sebagai berikut:

\begin{tabular}{ll}
\hline $\begin{array}{l}\text { Jenis-jenis } \\
\text { publikasi }\end{array}$ & $>$ Dr. Jufrizal \\
ilmiah & Syahri, M.Si \\
\hline Teknik & $>$ Rahmadini \\
$\begin{array}{l}\text { penulisan } \\
\text { jurnal ilmiah } \\
\text { dan praktek }\end{array}$ & $>$ Prafri, M.Sc \\
penulisan & \\
\hline Desain & $>$ Rahmiwati \\
penelitian & Hilma, M.Si \\
tindakan & $>$ Hasmalina \\
kelas & Nasution, M.Si \\
menjadi & $>$ Sri $\quad$ Hilma \\
jurnal ilmiah & Siregar, M.Sc \\
\hline
\end{tabular}

\section{HASIL DAN PEMBAHASAN}

Minat peserta pelatihan penulisan artikel ilmiah ini sangat tinggi, hal ini terlihat dari antusisme peserta mengikuti acara dari pagi sampai sore hari masih penuh semangat. Pelatihan ini memberikan pengetahuan baru terhadap guru-guru tentang tata cara penulisan publikasi ilmiah. Kegiatan pengabdian kepada masyarakat ini di awali dengan tahap persiapan. Tim pengabdian masyarakat melakukan persiapan alat dan bahan yang di perlukan untuk kegiatan pelatihan dan selanjutnya melakukan pertemuan di sekolah dengan wakil kepala sekolah bidang Humas. Setelah mengadakan pertemuan dengan wakil kepala sekolah tim pengabdian masyarakat melakukan pembagian tugas pada masing-masing tim pengabdian masyakat diantaranya persiapan ruangan, perlengkapan seminar di 
antaranya materi seminar, media pelatihan LCD, infocus, makalah serta dokumentasi kegiatan. Sasaran dalam kegiatan pengabdian masyarakat ini adalah guru-guru di SMA Negeri 2 Tambang Kabupaten Kampar. Berdasarkan hasil kesepakatan dengan wakil kepala sekolah bidang humas penyuluhan di lakukan di Laboratorium IPA SMAN 2 Tambang.

Tabel 1. Jadwal Kegiatan

\begin{tabular}{|c|c|c|c|}
\hline $\begin{array}{l}\text { Hari/ } \\
\text { Tanggal }\end{array}$ & Waktu & Aktivitas & $\begin{array}{l}\text { Penanggung } \\
\text { jawab }\end{array}$ \\
\hline \multirow[t]{6}{*}{$\begin{array}{l}\text { Jumat, } \\
\text { 09 Februari } \\
2018\end{array}$} & $\begin{array}{l}08.30- \\
09.00\end{array}$ & $\begin{array}{l}\text { Heregistrasi } \\
\text { peserta } \\
\text { workshop }\end{array}$ & Kesekretariatan \\
\hline & $\begin{array}{l}09.00- \\
09.30\end{array}$ & $\begin{array}{l}\text { Pembukaan } \\
\text { workshop } \\
\text { Sambutan } \\
\text { Ketua Panitia } \\
\text { Sambutan dan } \\
\text { sekaligus } \\
\text { membuka acara }\end{array}$ & M.C \\
\hline & \begin{tabular}{|l|}
$09.30-$ \\
10.30 \\
\end{tabular} & $\begin{array}{l}\text { Jenis-jenis } \\
\text { publikasi ilmiah }\end{array}$ & $\begin{array}{l}\text { Dr. Jufrizal } \\
\text { Syahri, M. Si } \\
\end{array}$ \\
\hline & $\begin{array}{l}10.30- \\
11.30\end{array}$ & $\begin{array}{l}\text { Teknik } \\
\text { penulisan jurnal } \\
\text { ilmiah dan } \\
\text { praktek } \\
\text { penulisan }\end{array}$ & $\begin{array}{l}\text { Rahmadini } \\
\text { Syafri, M.Sc } \\
\text { Prasetya, M.Si }\end{array}$ \\
\hline & \begin{tabular}{|l|}
$11.30-$ \\
13.00 \\
\end{tabular} & $\begin{array}{l}\text { Istirahat dan } \\
\text { sholat jumat }\end{array}$ & \\
\hline & $\begin{array}{l}13.00- \\
15.00\end{array}$ & 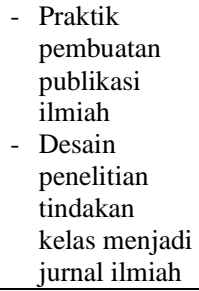 & $\begin{array}{l}\text { Rahmiwati } \\
\text { Hilma, M.Si } \\
\text { Hasmalina } \\
\text { Nasution, M.Si } \\
\text { Sri Hilma } \\
\text { Siregar, M.Sc }\end{array}$ \\
\hline
\end{tabular}

Kegiatan pengabdian kepada masyarakat dilakukan dengan cara tatap muka secara langsung dengan peserta pelatihan berjumlah 31 orang setiap kegiatan pengabdian masyarakat di lakukan. Kegiatan pelatihan dilakukan dengan metode ceramah dan diskusi dengan peserta kegiatan. Secara keseluruhan kegiatan pelatihan yang dilakukan berjalan dengan lancar dan tertib. Peserta antusias dalam mengikuti pelatihan yang terlihat pada saat kegiatan berlangsung di mana peserta pelatihan berperan aktif dalam sesi diskusi dan tanya jawab. Kegiatan pengabdian kepada masyarakat dilakukan dengan tiga tahapan kegiatan. Kegiatan pengabdian masyarakat yang pertama yaitu heregistrasi peserta, sambutan sekaligus membuka acara pada hari jumat, 09 Februari 2018 pada pukul 08.30 Wib s/d 09.30 wib. Peserta yang hadir pada kegiatan ini adalah guruguru SMAN 2 Tambang yang berjumlah 31 orang.

Kegiatan pengabdian kepada masyarakat yang kedua yaitu workshop publikasi ilmiah dan penelitian tindakan kelas yang disampaikan oleh para narasumber yang ahli dibidangnya masing-masing dan tentunya berkaitan dengan judul pengabdiannya pada hari yang sama pada pukul $09.30 \mathrm{Wib}$ s/d 11.30 wib. Terdiri dari dua sesi, sesi 1 yaitu materi tentang jenis-jenis publikasi ilmiah dan sesi II yaitu teknik penulisan jurnal ilmiah dan praktek penulisannya pada jumat, 09 Februari 2018 pada pukul 09.30 wib s/d 11.30 wib. Selanjutnya kegiatan pengabdian kepada masyarakat yang ketiga yaitu

praktik pembuatan jurnal ilmiah oleh peserta pelatihan. Output yang diharapkan setelah acara adalah, masing-masing peserta memiliki sebuah artikel yang sudah siap untuk di publikasikan dalam jurnal ilmiah. Peserta yang hadir pada kegiatan ini adalah guru-guru SMA Negeri 2 Tambang. Dokumentasi kegiatan berupa foto disajikan pada Lampiran foto.

Tabel 2. Jumlah Peserta Pengabdian

\begin{tabular}{|l|c|c|c|}
\hline No & Kategori Kegiatan & Jumlah & Persentase \\
\hline 1 & Kegiatan 1 & 31 & $100 \%$ \\
\hline 2 & Kegiatan 2 & 31 & $100 \%$ \\
\hline 3 & Kegiatan 3 & 31 & $100 \%$ \\
\hline
\end{tabular}

Berdasarkan table 2 terlihat bahwa $100 \%$ peserta workshop hadir di setiap kegiatan. Hal ini membuktikan antusiasme dan minat para guru di 
SMAN 2 Tambang dalam mengikuti pelatihan pembuatan publikasi ilmiah sangat tinggi. Workshop ini telah berhasil dan sukses dilaksanakan di SMAN 2 Tambang, terbukti dengan antusiasme para guru dalam mempraktikkan pembuatan jurnal ilmiahnya masing-masing yang nanti harapannya bisa dipublikasikan baik nasional maupun internasional.

Seluruh peserta antusias dengan kegiatan dan penjelasan yang di berikan oleh narasumber. Adapun Narasumber dalam kegiatan ini adalah 3 orang dengan rincian materi yangdisampaikan adalah :

1. Pembicara 1

Menyampaikan materi yang berkaitan dengan publikasi ilmiah serta jenis-jenis publikasi ilmiah

2. Pembicara 2

Menyampaikan materi yang berkaitan Teknik penulisan jurnal ilmiah dan praktek penulisan jurnal ilmiah atau publikasi ilmiah

3. Pembicara 3

Menyampaikan materi yang berkaitan dengan desain penelitian tindakan kelas menjadi jurnal ilmiah.

Pada saat kegiatan berlangsung terlihat bahwa para guru di SMAN 2 Tambang belum memahami dengan baik tentang pembuatan jurnal ilmiah dan bagaimana melakukan publikasi ilmiah. Dengan adanya kegiatan pelatihan ini maka diharapkan dapat meningkatkan pemahaman dan kemampuan guru SMAN 2 Tambang dalam membuat, melakukan publikasi ilmiah serta mampu mendesain penelitian tindakan kelas menjadi jurnal ilmiah sehingga tercapai tujuan dari pelatihan pembuatan publikasi ilmiah untuk guru-guru di SMA N 2 Tambang Kabupaten Kampar ini.

\section{Hasil kegiatan Pengabdian masyarakat secara garis besar mencakup beberapa komponen sebagai berikut :}

1. Keberhasilan target jumlah peserta pelatihan

Target peserta dari kegiatan workshop dan pelatihan ini adalah guru-guru SMAN 2 Tambang dan dalam hal ini tim pengabdian masyarakat telah berhasil merangkul guru-guru tersebut untuk ikut serta berpartisipasi dalam acara ini terbukti dengan hadirnya mereka baik disesi pertama dan juga disesi kedua dan kehadirannya melebihi $50 \%$.

2. Tercapainya tujuan pelatihan

Pada dasarnya tujuan dari penyuluhan ini adalah meningkatnya pemahaman dan kemampuan guru terhadap materi pelatihan, yang nantinya dapat digunakan sebagai acuan dalam pembuatan jurnal ilmiah oleh para guru-guru. Guruguru yang mendapatkan pelatihan diharapkan juga dapat menyebarkan informasi dan membimbing guruguru lain dalam membuat publikasi ilmiah. Melalui cara ini penyebaran informasi dapat berjalan lebih cepat selain itu dapat melengkapi persyaratan untuk naik pangkat/golongan.

Pada saat pelaksanaan kegiatan terlihat antusiasme peserta dengan berbagai pertanyaan yang dilontarkan oleh peserta. Pada saat klinik proposal, peserta diberikan suatu Lembar Kerja yang berisi isian permasalahan yang mereka temui di dalam kelas, selanjutnya dari Lembar Kerja ini peserta diharapkan dapat menemukan solusi dari permasalahan yang dituangkan dalam sebuah karya ilmiah. 


\section{KESIMPULAN}

Kegiatan Pelatihan Pembuatan Publikasi Ilmiah bagi Guru di SMAN 2 Tambang Kabupaten Kampar mendapat sambutan yang baik dari peserta dan berhasil dengan baik. Keadaan ini dapat dilihat dari kehadiran peserta yang hampir mencapai $100 \%$. Peserta terdiri seluruh guru di SMA N 2 Tambang, karena keterbatasan waktu, tidak semua karya ilmiah dapat terselesaikan oleh sebab itu dilanjutkan secara online, dimana peserta mengirimkan hasil rumusan Karya Ilmiah yang telah disusun lewat email dan instruktur melakukan review sekaligus revisi jika diperlukan untuk mencapai target luaran dari kegiatan ini.

\section{DAFTAR PUSTAKA}

1. Dwianto, A. 2016. Jenis publikasi ilmiah guru. Sang pengajar. Jakarta

2. Eko Putro Widoyoko. 2008. Penelitian Tindakan Kelas dan Pengembangan Profesi Guru. Disajikan dalam Seminar Nasional Peningkatan Kualitas Profesi Guru Melalui Penelitian Tindakan Kelas. Universitas Muhammadiyah Purworejo. 14 September 2004.

3. Harefa, Liberty, M. 2007. Pengembangan Kemampuan Berpikir Kreatif Siswa dengan Menggunakan Model Pembelajaran Berbasis Masalah pada Sub Pokok Bahasan Dampak Pembakaran Bahan Bakar Minyak Bumi. Tesis pada SPS UPI : Bandung

4. Permenpan dan RB No. 16 Th 2009 Tentang Jabatan Fungsional Guru dan Angka Kreditnya.

5. Suwardi Lubis. 2004. Tehnik Penulisan Ilmiah Populer. Universitas Sumatera

6. Utara: Fakultas Ilmu Sosial dan Ilmu Politik.
7. Wina Sanjaya. 2010. Penelitian Tindakan Kelas. Jakarta: Kencana.

8. Yunita T. Winarto, dkk. 2007. Karya Tulis Ilmiah Sosial: Menyiapkan, Menulis dan Mencermatinya. Jakarta: Yayasan Obor Indonesia. 